\title{
Some Practical Aspects of Interest
}

\author{
Joseph S. Taylor Pd. D.
}

To cite this article: Joseph S. Taylor Pd. D. (1898) Some Practical Aspects of Interest, The Pedagogical Seminary, 5:4, 497-511, DOI: 10.1080/08919402.1898.10534032

To link to this article: http://dx.doi.org/10.1080/08919402.1898.10534032

曲 Published online: 28 Aug 2012.

Submit your article to this journal 준

III Article views: 3

Q View related articles $\sqsubset$ 


\title{
SOME PRACTICAL ASPECTS OF INTEREST.
}

\author{
By Josepe S. Taylor, Pd. D., \\ Principal Public School No. I9, New York City.
}

The first systematic attempt to study children's interests seems to have been made by Alfred Binet in 1890 . His method was to question one child at a time as to certain common objects, such as knife, bread, doll, etc. From the data thus gathered he drew these conclusions :

I. That children are impressed to a very small extent by the visible aspect of things.

2. That their greatest interest is in the use of things.

3. That their ideas possess only slight abstract characteristics.

Prof. Barnes, acting upon the hint thus furnished by Binet, made a similar experiment in 1892 . The children were asked to tell on paper, without knowing what use was to be made of their answers, what the following are : $k$ nife, bread, doll, water, arm-chair, hat, garden, mamma, potatoes, bottle, flower. snail, mouth, lamp, earth-worm, shoes, finger, clock, house, wolf, omnibus, piece of sugar, thread, horse, table, bird, dog, carriage, pencil, balloon, village, box, handkerchief. ${ }^{1}$

This is the same list of words that Binet had employed. Barnes tested over two thousand children, and reached the following conclusions :

I. That at the age of seven, "use" is the thing of transcendent importance in the thoughts of children.

2. At the age of eleven " use" is still supreme, but "larger term" and "substance" are assuming importance. By "larger term" is meant referring an object to its genus; as, "a clock is a time-piece." By substance is meant what an object is made of ; as. " a clock is made of wood."

3. At fifteen "larger term" is more important than " use ;" "substance" and "structure" are getting more and more prominent.

At this point Dr. Shaw, Dean of the New York School of Pedagogy, took up the study, repeating what Barnes and Binet had done, but adding several new features. ${ }^{2}$

He had a larger number of objects, and classified his answers

${ }^{1}$ Studies in Education, p. 203. Stanford University.

${ }^{2}$ Child Study Monthly, August, 1896. 
under a larger number of heads. As a result of these variations, and also by reason of a different classification, by which answers appear under "action" that were classified under " use" by Barnes, Dr. Shaw is inclined to revise some of the opinions expressed by his two predecessors.

Another valuable investigation of interest from the practical side is that of Mary Sheldon Barnes on "The Development of the Historical Sense in Children." 1 One of her tests was to read a story without a date, a place, a name, or a moral, for the purpose of finding out what questions children would spontaneously ask. The other test consisted of two parts : I. Children were asked to write down something that happened before they were born, and tell how they knew it was true 2. They were asked to explain how they knew that George Washington ever lived. Among Mrs. Barnes's conclusions are these :

I. History is a proper subject for children from the age of 7 .

2. Time is badly understood until $\mathrm{I}_{2}$ or $\mathrm{r}_{3}$, hence it should be visualized by means of charts.

3. Children should not be specially trained or urged in inference until ${ }_{2} 2$ or 13 .

4. History should first interest itself with the biography of heroic characters.

5. These biographies should be of men who fight, and hunt, and build, rather than of those who write, or think, or legislate.

About two years ago it occurred to me that some criterion of the value of educational work might be found by ascertaining the attitude of children toward the different subjects of the curriculum. If it be granted that a suitable subject properly taught interests a child, it follows that where interest is wanting, the fault must lie either in the course of study, or in the teaching, or in both.

Having obtained permission from the Principal of one of the Boys' Departments of a New York Public School, I requested the teacher of every class to submit to the pupils these four questions :

I. What subject or subjects did you particularly like in your last class?

2. Why did you like them?

3. What subject or subjects did you particularly dislike?

4. Why?

The study was made in September, just after the long vacation. It was assumed that any like or dislike that was remembered after ten weeks must be a reality and not a mere passing whim. If such questions were put in the middle of a term the answers would have far less value than under the conditions

${ }^{1}$ Studies in Education, p, 43. 
adopted, because a child is prone to like the subject in which for the time being be gets high marks. By summoning his judgment to a period long past, only those experiences which, on the whole, impressed him most will be taken into account.

The number of pupils examined was about a thousand, but for various reasons only 756 papers were available for study. The results were tabulated by ages, grades, subjects, and classes. In Table No. I are shown the results by age and grade.

In September, 1897, two more studies were undertaken along the same lines, one of a New York Mixed School, and another of the Public Schools of Winona, Minn.

In Tables 2, 3, 4, and 5 are found the results of these studies, aggregating, with the former study, returns from 2, I37 pupils.

The columns of each of the tables have been averaged, and these averages may be taken to measure the interest of children in their school studies. No children below the third grade were examined. For the ages of 8 and 17 only a few returns were received, consequently the figures found in these columns have but little value. If we accept the Herbartian contention that interest is a test of good teaching, then, in a good school, the pupils ought to become more and more deeply interested as they pass from age to age and grade to grade. Table No. I shows that this is definitely the case in the Boys' School of New York, where the averages range in regular gradation from 20 to 37 for ages, and from i 8 to 45 for grades. In the Mixed School (No. 4), there is a noted decline of the interest curve, beginning at the age of 13 for both boys and girls. This seems to be due to the teaching in the fifth grade, where there is a remarkable falling off in interest. In the preceding grade 60 per cent. of the girls liked arithmetic, here only 20 ; 40 per cent. were fond of geography, 44 per cent. of history; now only $2 \mathrm{I}$ per cent. care for geography, and 23 per cent. for history.

In the Winona Table (No. 2) there is also a similar dip at 13, and one covering the fifth and sixth grades of girls; the boys, on the contrary, are quite as regular as those of the New York Boys' School. So also in Table No. 4, the boys show less variation than the girls. The principals of these schools may be able to explain these facts. Are they phenomena of sex, or adolescence, or simply results of the teaching process?

In New York the girls are more interested than the boys; in Winona the case is reversed.

1 Acknowledgment is hereby made of valuable services rendered by the following persons: Prof. E. A. Kirkpatrick secured the Winona returns through the courtesy of Mr. J. A. Tormey, Supt. of the Winona Schools, and my wife tabulated the same. Dr. E. R. Birkins, Principal of Public School No, ro, New York City, secured and tabulated all the returns in Tables 4 and 5. ) 


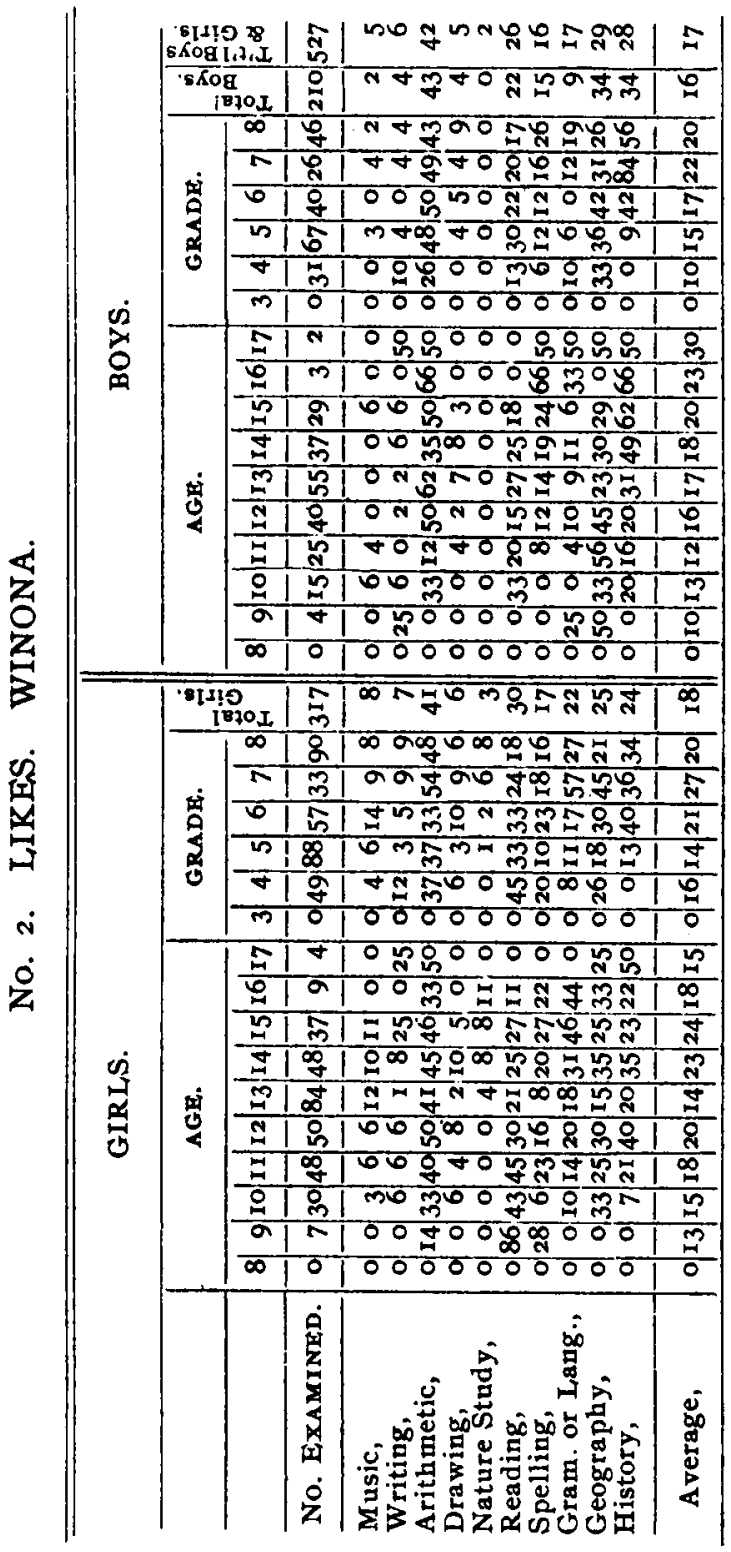




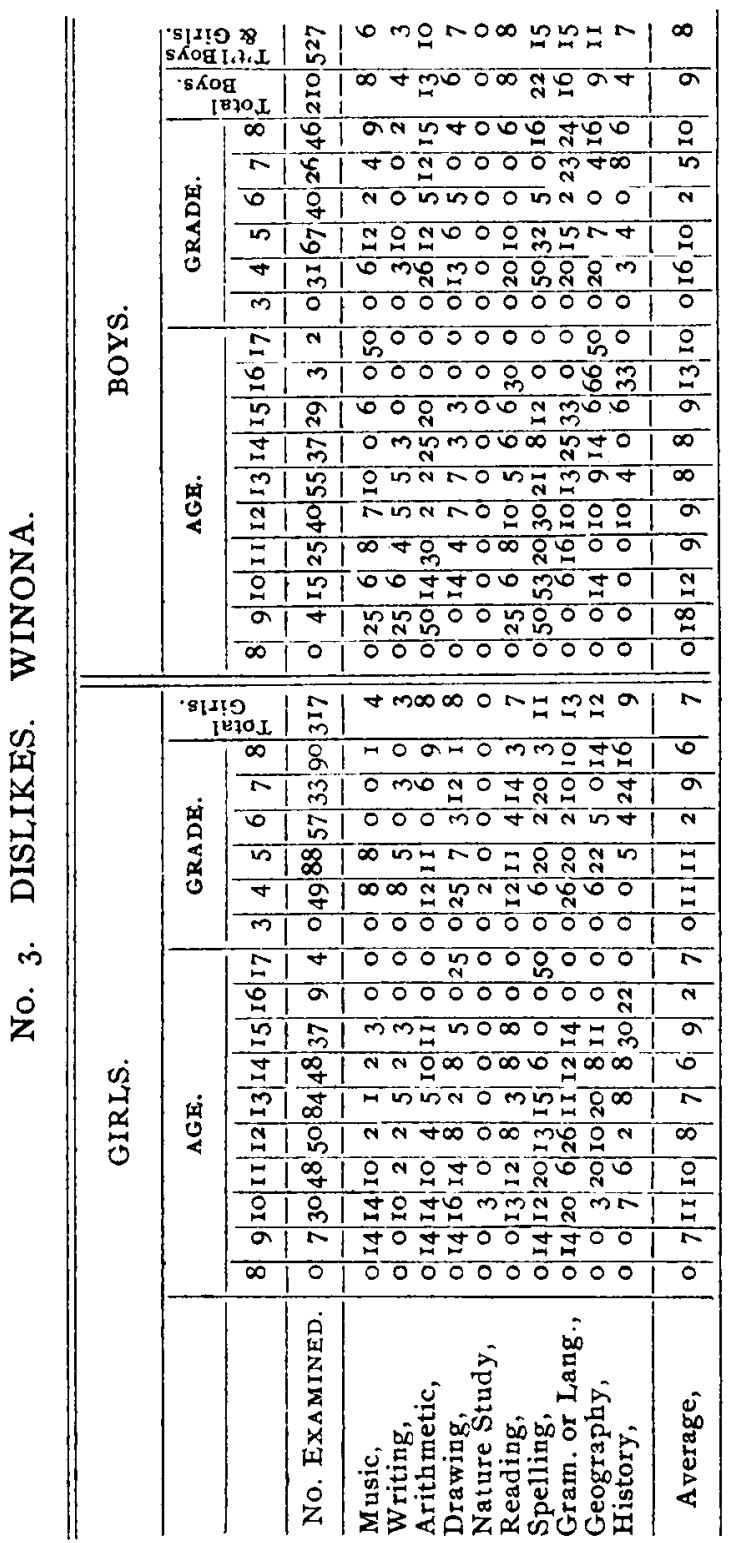


SOME PRACTICAL ASPECTS OF INTEREST.

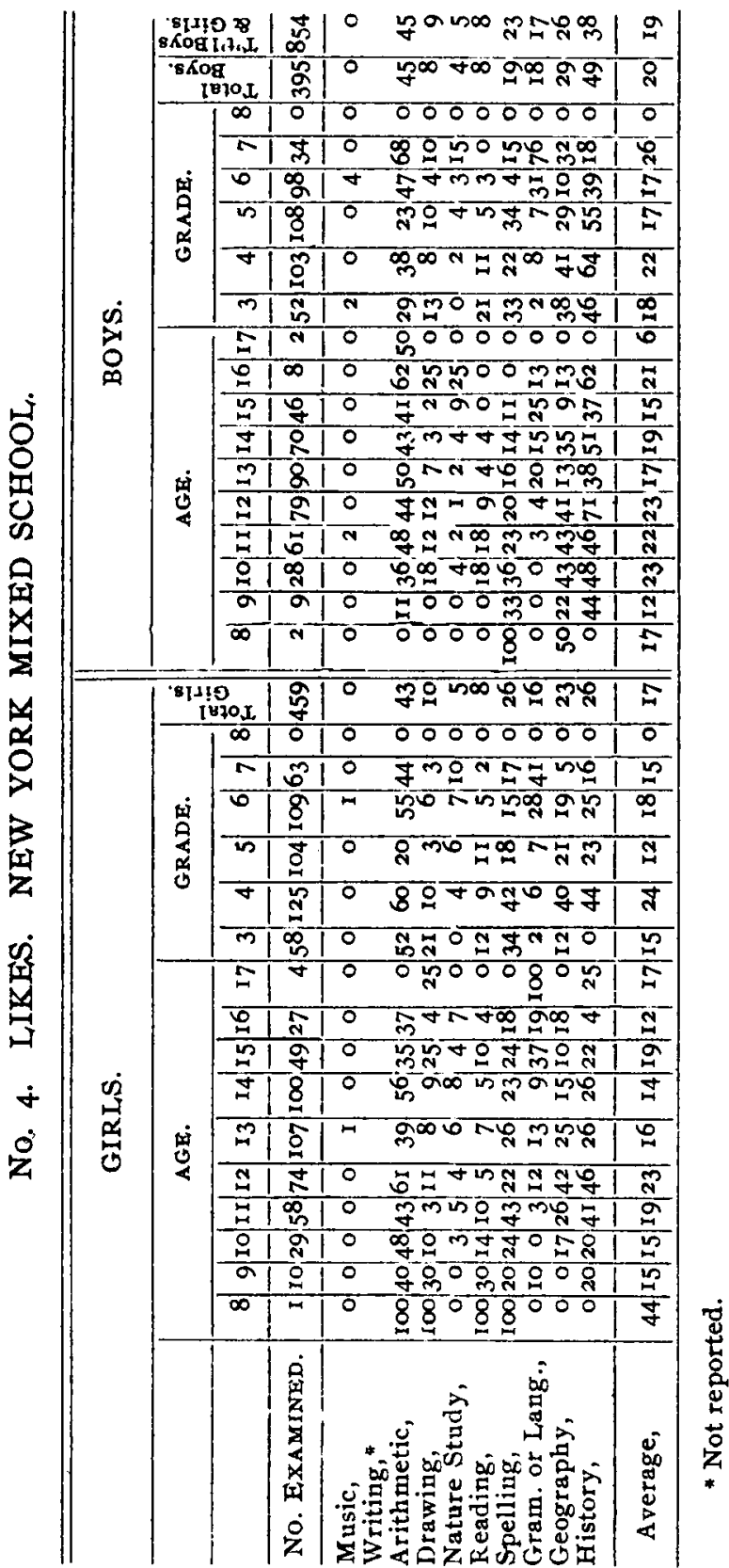




\section{ArIThMeTIC.}

In all schools arithmetic is a subject of trauscendent interest, the lowest average being 36 , the highest 45 . Boys are a little more interested in it than girls. The dislike of the subject is almost equally prominent. So much time is devoted to it in our programmes that it affects children very profoundly. More than half the pupils name the subject as either a like or dislike. The average of the likes is 42 ; of the dislikes, 14 . In New York more boys have a distaste for it than girls. In Winona it is the other way.

\section{HISTORY.}

Next in popularity is history. The studies of Barnes and Shaw have shown that children like "use" and "action;" hence we can see why history should be a favorite study, inasmuch as it deals with movement in the form of discovery, exploration, and battle. The average of all schools is 38 per cent. for the likes, and 7 for the dislikes.

\section{Geography.}

Geography is next in importance. The average likes range from 23 to 29 , the dislikes from I I to 21 . The unpopularity of the subject among the girls in Table 5 suggests a defect of method in some of the grades of that school, especially the third, fourth, and seventh.

\section{SPELIING.}

What is there in the spelling of the English languge to commend it to the heart of a child? Twenty-two per cent. of the two thousand pupils declare that they are particularly fond of it. But nearly one-tenth of all profess an aversion to it. Our New York methods seem to succeed better than the Winona methods.

\section{READING.}

Reading enlists the interest of 19 per cent., and 5 per cent. dislike it.

\section{Grammar.}

Grammar and Language studies are far from successful in any school, if interest is a criterion. The best work seems to be done in the New York Mixed and the Winona Schools, the average of likes for both being 17 per cent. Boys are much less interested than girls, the numbers being respectively I $_{3}$ and 19. In New York Mixed School 27 per cent. of the boys dislike grammar. Is it possible to make this study interesting to the average child? If so, we need to examine our methods 
and find out why about one-seventh of the pupils like it, oneseventh dislike it, and the rest are indifferent.

\section{DRAWING.}

What is the matter with drawing? In one school 9 per cent. (No. I), in another 8 per cent. dislike it. I charge the dislikes in New York to the old course of study, which has recently been replaced by a better one. For Winona I cannot speak; but it seems strange that in the fourth grade 25 per cent. of the girls and 26 per cent. of the boys should dislike a subject which is supposed to be one of the spontaneous modes of childish expression.

\section{WRITING.}

Writing has little attraction for children. One school made no report on the subject; the average of the rest is 8 for the likes and 5 for the dislikes.

\section{MUsic.}

If a foreigner looked at the returns for music he might come to the conclusion that the soul of the American has no sense of harmony. "Heavenly harmony," and only 2 per cent. like it, while 4 per cent. hate it, and the rest are indifferent! A part of this indifference is accounted for by the fact that only a small portion of time is devoted to it (in New York, Io minutes a day), but even with this allowance, there is grave suspicion that music in the public schools is largely a failure.

\section{NATURE STUdY.}

I have left nature study for the last, beca use the returns seem to me to show a prodigious waste of school energy. ${ }^{1}$ Col. Parker insists that nature studies constitute the spontaneous interests of childhood, and should therefore be the "central subjects" of the course of study, all the rest being merely " modes of attention," "modes of judgment," or "modes of expression." If half of Col. Parker's claim is true, how have we sinned against childhood, when only 4 per cent. of our pupils have any interest left in nature, and 7 per cent. profess disgust! In Winona there is utter indifference, less than two per cent. having professed interest, while the rest do not consider it of sufficient importance even to dislike it. In New York the case is a little better, but far from satisfactory. In

${ }^{1} \mathrm{~A}$ friend who was kind enough to read the manuscript of this article suggests that it might be well to make some allowance for the fact that failing to mention such subjects as nature study and music, may be due not to indifference, but to the pupils not regarding them as subjects of study owing to the absence of text books. 
Mr. I,ancaster's study of adolescencel we find that out of the $1, \infty 00$ eminent men and women studied, 640 were ardent lovers of nature, while only 290 of the same individuals liked any one science. What more eloquent arraignment of our present methods of science teaching could be imagined than this contrast between the love of nature on the one hand and the distaste for science on the other.

Five or six years ago Supt. Seaver made a report on the teaching of elementary science in Boston, in which he said that nature study was gravely deficient, both in method and in results. "Notwithstanding the work of Miss Crocker, the Normal School, and the teachers' school of science," he says, "it remains a fact that the sciences - particularly the natural history sciences - have very little lodgment in our current school work. And this statement must be made more than a generation after the great Agassiz began his work of promoting an interest in the study of natural history among all people, all schools, and all teachers." 2

In 1893, Prof. Dolbear, of Tufts College, read a paper in which he said: "The results of the teaching of science in schools of all kinds have been a great disappointment to the friends and advocates of science teaching."

The reason for this disappointment is found in the fact that we have hitherto confused two things wholly different. We have mistaken systematic science for nature study.

No mistake has been more common than the attempt to teach to small children the results of science. This is a psychological error which assumes that what was a normal experience of Newton, Gray, or Darwin, may become an experience of the little child. Who does not know that zoölogy, for instance, is reduced to a skeleton, then presented in abstract and logical form to children as a product of science? Yet neither the logic nor the abstraction is possible to the young learner. The protests of Dr. Hall and Dr. Hodge, ${ }^{8}$ as well as of Prof. Dewey, ${ }^{4}$ are certainly well taken, and these returns show how utterly futile it is to try to interest children by giving them the abstract, logical, completed summaries of adult science.

\section{REASONS. 5}

The reasons which the children gave have not been tabulated, but below will be found some typical answers.

\footnotetext{
1 Pedagogrcal Seminary, V: $\mathrm{I}$ - p. 6r.

2 Ed. Review, Oct., '9I.

Summer School of Clark University, I897.

4 "Psychological Aspect of the School Curriculum," Ed. Review, April, 1897.

${ }_{B}$ For this selection of reasons, I am indebted to Dr. E. R. Birkins, of New York.
} 


\section{YHARS OF AGE.}

\section{Likes.}

G. "I like history because it is very interesting."

G. "I liked to hear about the great men like Columbus."

G. "Arithmetic, because it teaches me how to add and subtract."

B. "It was about different country and ours" (History).

B. "History. It has storys about wars."

B. "History. It is the interesting early life of our country."

B. "History and Geography because they are the most interesting of any studies."

\section{Dislikes.}

G. "Arithmetic-because it is tiresome."

G. "Arithmetic-I thought it was hard."

B. "Geography-because it was too easy."

B. "Geography-because it was too hard."

G. "Geography-because I do not like to look up the map."

B. "Arithmetic, Spelling and Writing. Because they are the most tiresome studies."

\section{YEARS OF AGE. \\ Likes.}

G. "Arithmetic and Drawing-because they are the best, and the hardest."

B. "Arithmetic. Because it requires a good deal of thinking."

B. "Arithmetic History and Geography-because they will help me in later life."

G. "Spelling, History and Arithmetic-because they were always explained so that we could understand them."

G. "Grammar as it was like a puzzle."

G. "Reading. Because it has many tales in it."

G. "History and Geography-because it is nice to know about the world and its people."

B. "History. Because it tells of all the great men of the world."

G. "Spelling. Because it is very important."

B. "Geography. Because it is something interesting."

G. "Arithmetic, Spelling, Reading. I liked these studies because they were teaching me to have a good education."

B. "Arithmetic, Because I had to think."

\section{Dislikes.}

G. "Copy-Book Writing. Because I can't write good."

G. "Grammar. Becanse I could never get it right and I used to try very hard."

B. "History and Physiology. Because I did n't study it enough."

B. "Drawing. Because I did not have a taste for it."

B. "Physiology. Because it talks to much about skeletons."

B. "I dislike no study."

G. "Music. I did not learn it in the primary and it was hard for me."

G. "Physiology, as it gave me fancies."

B. "I don't like spelling very much."

G. "Geography-because I cant understand it and never will."

$G$. "I never knew what to write in composition and writing got me tired."

B. "I don't like Suffixes because you get mixed up."

G. "Prefixes. Becaúse they would catch me." 
I3 YHARS OF AGE.

Likes.

G. "Geography-because it tells about the world."

G. "Grammar-because it teaches us how to talk correctly."

G. "Arithmetic-because it helps us to get a position."

G. "Arithmetic, Reading-because I was best in them."

B. "Arithmetic. Because it is used most in business."

B. "Reading. Because I learn something about great men."

B. "Geography and History. Because they are more interesting than others."

B. "History. Because I liked to hear about wars and adventures."

\section{Dislikes.}

G. "Physiology. Because I found it not easy to learn."

G. "Arithmetic. Because it is very difficult to learn."

G. "Dictation-because I never got it all right."

G. "Geography-because I could n't remember it."

B. "Prefixes and Suffixes. Because they were to dry."

B. "Physiology-because it was not interesting."

B. "Geography-because it was hard."

\section{I5 YEARS OF AGE. Likes.}

G. "Geography, History. Because they teach us something about the country.'

B. "If I should go into a wholesale house I would need decimals very much."

G. "Arithmetic-because I like to puzzle it out."

G. "Grammar-because it gives us power to speak English properly."

B. "History-becanse I am fond of reading about battles and famous men who fought in them."

B. "Grammar-because it teaches us to speak correctly.

B. "Arithmetic. Because it is a useful study."

B. "Physiology-you can help iujured people or drowned people.",

B. "Arithmetic-because there is so much reasoning to be done."

G. "Arithmetic--as it was explained very distinctly."

G. "Physics-beouse it is so interesting."

Dislikes.

G. "I did not care for arithmetic as much as my other studies just because I did not always know how to do it."

G. "None-because they are all of use to us."

G. "Composition-because I was not a good composer."

B. "German-because it is so difficult to get the articles in the right place."

B. "I don't dislike any but the one I like least is German."

B. "Physiology. Because business people don't like it."

B. "Synonyms-becsuse I could not very well understand them then."

G. "Arithmetic-because I was very poor in this study."

B. "Grammar-because I did not see what use it would be in business."

\section{I7 YEARS OF AGE. Likes.}

G. "Arithmetic-because it is most important to know how to figure." 
G. "Grammar-because it is very interesting to know how our lan: guage is formed, and it is also very necessary."

$G$. "Composition-because $I$ am fond of trying to compose."

B. "Arithmetic-because it is most beneficial."

B. "Geography-because it is a very interesting and useful study."

\section{Dislikes.}

G. "Arithmetic-because it is very complex and difficult to understand."

G. "Geography-because there is a great deal to remember."

\section{A Few Nover Reasons. ${ }^{1}$}

B. "I like Geography because I entend to become a navagitor."

B. "I have a strong aversion to werbs."

G. "I don't like writing because it make my hand taller." (An Italian girl.)

B. "I did not like Drawing besause it is to dirty using rubbers." (ro years old.)

B. "I liked them all but I liked History picterly." (ro years old).

B. "Arithmetic-because it is the most emported thing that we must learn."

G. "Roots-because it puzzles me."

G. "We had to hard Drawing we had to make free hand circles and free hand squeers."

B. "Writing--because it makes you tired." (9 years old.)

\section{CONCl,USIONS.}

1. Such a study as this is useful to a principal because it enables him to locate poor teaching. The Teachers' Conference is to remedy defects. I believe this is an infallible method of discovering in what subjects and grades the defects exist. If he finds that 52 per cent. of the third grade like arithmetic, 60 per cent. of the fourth grade, and only 20 per cent. of the fifth, there is pretty conclusive evidence that something is wrong in the fifth grade. And such a discovery may be made in a class whose teacher is in every other respect successful, and has an excellent record.

2. It is useful to a principal, also, because it furnishes a criterion for rating the teacher. I believe that interest, rather than a per cent., is the true test of a teacher's success. The present method of estimating a teacher's success is by the number of facts her pupils remember. If, instead of this, the teachers were tested by the touchstone of interest, what a revolution it would work on the pedagogical balance-sheets of the superintendent's office. Many a teacher who counts himself rich on the basis of past methods, would suddenly find himself bankrupt. And many another, who has perhaps been regarded as a pauper, would find himself the possessor of a fortune. Some of the most successful crammers are murderers of interest.

3. If such studies are useful to the principal, they are no less valuable to the teacher. When the study was made in the

\footnotetext{
"A nine year old boy liked his former teacher because "she was not craws."
} 
Boys' School, 76 per cent. of those who studied geometry expressed a dislike for it. I called the teacher's attention to the fact, and he was greatly surprised. On reflection, it occurred to him that the reason must be that he undertook to do more than the class were able to stand. He had been told that he must cover a certain number of pages in a year, and he proceeded to lay out his work accordingly. His pupils happened to possess very meagre average capacity, and so they failed to understand their geometry. There was no time for apperception. In consequence of this study, the teacher reversed his methods and determined that he would cover the ground only as fast as his pupils could do it thoroughly. Three months later he polled the same class again, whereupon 75 per cent. declared that they especially liked geometry.

4. It is known that the majority of pupils in the public schools never reach the higher grades. Very many leave permanently at the end of the third year. Prof. C. M. Woodward has ascertained that in St. Louis the average age of pupils at the time of withdrawal from school is thirteen years. In New York it is not uncommon to see in a school four or five crowded fourth grade classes and one seventh grade. Some of these early withdrawals are made necessary by the poverty of parents, especially of widows. Others are due to the cupidity of parents, who value above a good education the few paltry dollars their children can earn. But is it not also a fact that a large number of children leave school voluntarily because they are not interested in their studies? All truants certainly belong to this class. The hardest part of every teacher's work is the management of the apathetic, uninterested pupils. These are the ones who make most of the trouble in discipline; who tax the teacher's time and patience; who fall behind and injure the record of the class when examinations and promotions come round.

I am one of those who believe that there is no such thing as a "lazy" child. Many are ill, and suffer from a lassitude which is pathological. But the majority of the so-called "lazy" and "indifferent" are simply children who are not interested in the course of study.

Studies like the present will go far to show not only who the uninterested children are, but the reasons they give for their likes and dislikes often suggest a remedy by revealing the obstacles in the child's way.

5. Finally, it is a test of the success or failure in the management of a school or a system. Better than the testimony of the teachers and principals; more certain than any percentages of achievement ; more reliable than show-work put up in the class-room or sent to an exhibition, is this silent but eloquent testimony of the children as to the success or failure of methods and courses of study. 